\title{
MENINGKATKAN PRESTASI BELAJAR SISWA KELAS IX-5 SMP N 2 BABALAN DENGAN METODE PEMBELAJARAN KOOPERATIF TPS (THINK PAIR SHARE) TERPADU
}

\author{
T. Ridanti \\ Surel : wija.sseptian@gmail.com
}

\begin{abstract}
ABSTRAK
Hasil wawancara dan observasi awal dilakukan di SMP Negeri 2 Babalan diketahui bahwa Guru kelas IX-5 menggunakan metode ceramah dalam kegiatan pembelajaran, hal ini menyebabkan siswa kurang memahami materi. Data yang diperoleh dalam penelitian ini berupa aktivitas dan hasil belajar siswa. Aktivitas siswa diamati selama pembelajaran, sedangkan hasil belajar diukur di setiap tes akhir siklus. Instrumen yang digunakan berupa lembar observasi, soal tes dan catatan lapangan. Hasil penelitian menunjukkan adanya peningkatan hasil belajar siswa yang diketahui berdasarkan nilai rata-rata siswa, sebelum adanya penerapan model pembelajaran kooperatif TPS (Think Pair Share) nilai rata-rata kelas siswa adalah 66,20 setelah penerapan model pembelajaran kooperatif TPS (Think Pair Share) pada siklus I dengan nilai ratarata 69,33 dan pada siklus II rata-rata 76,73.
\end{abstract}

Kata Kunci: Think Pair Share, Hasil Belajar, Kooperatif

\section{PENDAHULUAN}

Pendidikan merupakan salah satu sektor penting yang harus ditangani oleh suatu bangsa, karena pada hakekatnya pendidikan merupakan proses untuk membangun manusia dalam mengembangkan dirinya agar dapat menghadapi segala perubahan dan permasalahan yang terjadi dilingkungan sekitarnya.

Kekurangaktifan siswa yang terlibat dalam proses pembelajaran dapat terjadi karena metode yang digunakan kurang melibatkan aktivitas siswa secara lansung. Pembelajaran dikelas masih banyak didominasi oleh guru sehingga kurang mampu membangun persepsi, minat dan sikap siswa yang lebih baik. Kebanyakan siswa mengalami kebosanan dikarenakan model pembelajaran yang berpusat pada guru sehingga kurangnya minat dan sikap siswa tersebut berdampak terhadap prestasi belajar yang secara umum kurang memuaskan.

Menurut Hamalik (2003: 137), pada hekekatnya keaktifan belajar dan terdapat pada semua perbuatan belajar, tetapi pada kadarnya yang berbeda-beda tergantung pada jenis kegiatannya, materi yang dipelajari dan tujuan yang hendak dicapai.

Pembelajaran yang kooperatif muncul dari konsep bahwa siswa akan lebih mudah menemukan dan memahami konsep yang sulit jika mereka saling berdiskusi dengan temannya. Pembelajaran kooperatif merupakan sebuah kelompok strategi pengajaran yang melibatkan siswa bekerja secara 
berkolaborasi untuk mencapai tujuan bersama (Trianto, 2007: 42).

Berdasarkan hasil observasi awal yang dilakukan di SMP N 2 Babalan kelas IX-5 Tahun Pelajaran 2015/2016 menunjukkan bahwa pencapaian kompetensi mata pelajaran ekonomi pada IPS terpadu didapati siswa yang kurang optimal. Dari data yang didapat diketahui bahwa kelas IX-5 merupakan kelas yang paling rendah prestasinya dari pada kelas IX yang lain. Rata-rata nilai mata pelajaran IPS kelas IX-5 adalah 66,20 sedangkan nilai siswa yang mendapat nilai lebih dari 70 hanya 8 siswa.

Masalah rendahnya prestasi belajar siswa mata pelajaran IPS setelah diidentifikasi bersama guru IPS yang lain disebabkan adanya minat siswa yang masih rendah, siswa kurang termotivasi untuk belajar karena pembelajaran hanya menggunakan model ceramah dan pembelajaran secara monoton tanpa ada variasi tertentu.

Berdasarkan permasalahan yang ada, maka guru dan peneliti merasa perlu untuk mengadakan penelitian terhadap strategi pembelajaran berkaitan dengan model pembelajaran yang digunakan oleh guru. Dalam hal ini, peneliti dan guru sepakat menerapkan model pembelajaran kooperatif TPS (Think Pair Share). Berdasarkan pembelajaran kooperatif, peneliti ingin mengembangkan model TPS untuk mengembangkan penguasaan materi dan keaktifan siswa dalam proses pembelajaran yang akan berpengaruh pada prestasi belajar siswa dalam mengolah, mencari dan mendiskusikan dengan teman dalam kelompok kecil.

Metode ini dikembangkan oleh Frank Lyman dan rekan-rekan dari Universitas Maryland pada tahun 1985. Keunggulan dari metode TPS (Think Pair Share) adalah mudah untuk diterapkan pada berbagai tingkat kemampuan berpikir dan dalam setiap kesempatan. Siswa diberi waktu lebih banyak berpikir, menjawab dan saling membantu satu sama lain. Prosedur yang digunakan juga cukup sederhana. Bertanya kepada teman sebaya dan berdiskusi kelompok untuk mendapatkan kejelasan terhadap apa yang telah dijelaskan oleh guru bagi siswa tertentu akan lebih mudah dipahami.

Think Pair Share adalah suatu strategi pembelajaran yang tumbuh dari penelitian pembelajaran kooperatif dan waktu tunggu dan dirancang untuk mempengaruhi pola interaksi siswa. Menurut Agus Suprijono (2015), dalam kegiatan model TPS (Think Pair Share) diharapkan terjadi tanya jawab yang mendorong pada pengkonstruksian pengetahuan secara integrative dan peserta didik dapat menemukan struktur dari pengetahuan yang dipelajarinya.

Langkah-langkah pada proses pembelajaran kooperatif TPS (Think Pair Share) yaitu (1) berpikir (Thingking), (2) berpasangan (Pairing), (3) berbagi (Sharing) (Trianto, 2007). Dalam tahapan Thinking, Pairing dan Sharing, 
kecakapan siswa dalam komunikasi yang meliputi kecakapan mendengar, berbicara, membaca maupun menuliskan gagasan atau pendapatnya ketika pembelajaran berlansung akan terlihat. Adanya pemberian masalah dilakukan untuk melihat penguasaan dan pemahaman siswa mengenai materi yang telah dipelajarinya.

Diskusi dalam bentuk kelompok kecil sangat efektif untuk memudahkan siswa dalam memhami materi dan memecahkan suatu permasalahan. Dengan cara ini siswa diharapkan mampu bekerja sama, saling membutuhkan, dan saling bergantung pada kelompokkelompok kecil secara kooperatif.

Tujuan penelitian ini adalah meningkatkan prestasi kelas IX-5 SMP N 2 Babalan pada mata pelajaran IPS Terpadu melalui penerapan model pembelajaran kooperatif TPS ( Think Pair Share).

\section{METODE PENELITIAN}

Penelitian ini dilakukan di SMP N 2 Babalan kelas IX-5 Tahun Pelajaran 2015/2016, alasan pemilihan lokasi penelitian dikarenakan sekolah tersebut belum pernah digunakan untuk penelitian sejenis dan guru di sekolah tersebut belum banyak mengenal mengenai pembelajaran kooperatif khususnya TPS (Think Pair Share).

Waktu pelaksanaan penelitian dilakukan dari bulan nopember 2015 sampai dengan april 2016 dengan subjek penelitian adalah siswa kelas IX-5 SMP N 2 Babalan Tahun
Pelajaran 2015/2016. Jenis penelitian yang dilakukan adalah Penelitian Tindakan Kelas (PTK), yang tidak menguji hipotesis secara kuantitatif tetapi lebih bersifat untuk mendeskripsikan data, fakta dan kegiatan yang ada.

Instrument pengumpulan data yang dilakukan berupa metode observasi, wawancara, dokumentasi dan tes hasil belajar.

Prosedur penelitian yang dilaksanakan direncanakan dalam tiga kali pertemuan dalam satu siklus yaitu (1) Perencanaan Tindakan, meliputi a) kegiatan yang dilakukan dalam penelitian berupa penyiapan perangkat pembelajaran, berupa silabus, RPP dan skenario pembelajaran yang menggunakan model pembelajaran kooperatif Think Pair Share (TPS), penyusunan instrument penelitian dan menetapkan indikator ketercapaian, instrumennya berupa lembar observasi, c) penyiapan sumber bahan yang sesuai standar kompetensi dan kompetensi dasar; (2) Pelaksanaan Tindakan; tindakan yang dilaksanakan dalam penelitian ini bertujuan untuk meningkatkan keaktifan dan prestasi belajar siswa yang sebelumnya dirasakan kurang menarik dan kurang maksimal, (3) Observasi; merupakan proses perekaman dengan mengamati semua peristiwa dan kegiatan yang terjadi selama penelitian tindakan kelas berlansung, yang meliputi; a) kondisi atau suasana belajar, b) prestasi belajar siswa, c) keaktifan siswa, kemampuan mengerjakan soal 
diskusi, d) tanggapan terhadap strategi pembelajaran, (4) Analisis dan Refleksi, mencakup analisis, interpretasi dan evaluasi atas informasi yang diperoleh dari kegiatan observasi. Berdasarkan pelaksanaan tahap observasi dan evaluasi sebelumnya, data yang diperoleh selanjutnya menjadi bahan refleksi bagi peneliti untuk perbaikan metode pembelajaran pada materi berikutnya (pada siklus n).

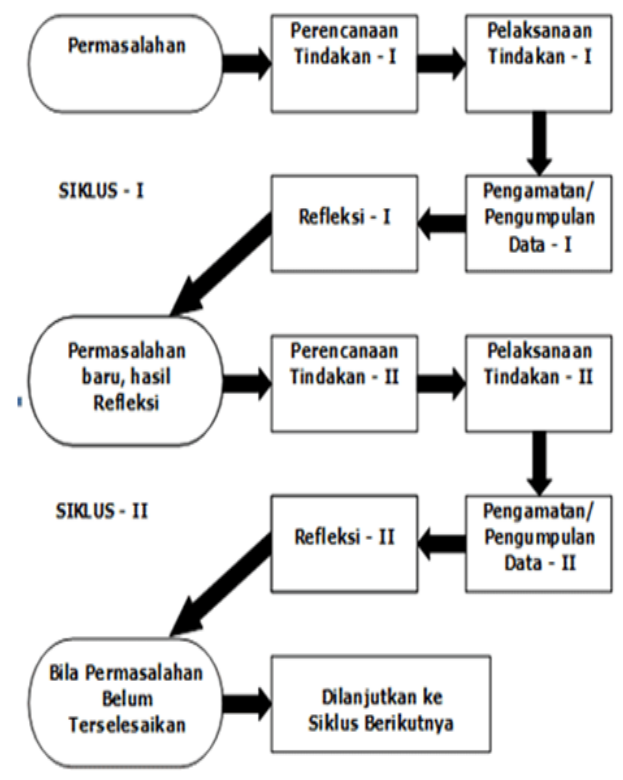

Gambar Bagan Prosedur PTK (Arikunto :2006)

Posedur penelitian tindakan kelas secara rinci adalah:

a. Siklus I, meliputi beberapa tahapan: (1) Merencanakan tindakan, (2) Melaksanakan observasi, (3) Membuat refleksi, (4) Melakukan revisi.

b. Siklus II, meliputi beberapa tindakan: (1) Merencanakan tindakan berdasarkan revisi siklus I, (2) Melaksanakan tindakan sesuai rencana yang telah diperbaiki pada siklus I, (3) Melaksanakan observasi terhadap tindakan pelaksanaan.

\section{HASIL PENELITIAN DAN PEMBAHASAN}

a. Perencanaan Tindakan yang meliputi: (1) menyiapkan perangkat pembelajaran; menyiapkan silabus, RPP yang lengkap dengan scenario pembelajaran, (2) menyiapkan instrument; terdiri dari lembar observasi, (3) menyiapkan materi yang sesuai dengan standar kompetensi dan kompetensi dasar, (4) menyiapkan media pembelajaran yang diperlukan sesuai dengan scenario pembelajaran, mendesaian alat evaluasi berupa soal kuis.

b. Pelaksanaan Tindakan

Dilaksanakan tiga kali pertemuan dengan alokasi waktu 6 x 45 menit sesuai dengan RPP, dengan materi yang disampaikan tentang kebijaksanaan pemerintah dibidang fiscal dipertemuan pertama, diskusi dan presentasi di pertemuan kedua dan evaluasi di pertemuan ketiga.

Observasi dan Interprestasi. Dilakukan pengamatan dengan pedoman lembar observasi yang telah disusun, dilaksanakan bersamaan dengan pelaksanaan tindakan.

Hasil penerapan model pembelajaran kooperatif TPS meliputi: (a) Visual Activities, dengan kreteria baik sekali, baik, cukup, kurang dan kurang sekali, yang dilakukan pengamatan sebelum dan pada saat Siklus I; (b) Oral 
Activities; (c) Listening Activies; (d) Writing Activities.

Pada siklus I terdapat peningkatan hasil belajar siswa dibandingkan sebelum diterapkannya model pembelajaran TPS, hal ini terlihat dari rata-rata kelas sebelum hanya 66,20 tetapi setelah penerapan model pembelajaran TPS nilai rata-rata mencapai 69,33 . Jumlah siswa yang mencapai nilai diatas 65 adalah 23 siswa atau sekitar $57,50 \%$ siswa tuntas dari jumlah keseluruhan sebanyak 40 siswa. Dari data tersebut peneliti menyadari kelemahan yang ada di siklus I antara lain: a) kurang pengawasan dalam pembelajaran di dalam kelas; b) masih pasifnya siswa saat diskusi kelompok. Untuk itu peneliti menjadikan ini dasar untuk melakukan siklus II.

Perencanaan Tindakan II yang meliputi: (a) penyiapan silabus, RPP yang lengkap dengan scenario, dilanjutkan dengan diskusi dengan peneliti selaku pengajar yang akan menerapkan model pembelajaran Think pair Share (TPS); (b) menyiapkan instrument, instrument yang terdiri dari lembar observasi mengenai model pembelajaran kooperatif Think pair Share (TPS) untuk mencatat hasil pengamatan kegiatan siswa dari awal sampai akhir pembelajaran. Pelaksaan Tindakan II. Dilaksanakan selama 3 kali pertemuan dengan alokasi waktu 6 x 45 menit sesuai dengan scenario pembelajaran dan RPP. Materi pada pelaksanaan tindakan II adalah pajak dan pungutan resminya serta penghitungan pajak penghasilan dan pajak bumi dan bangunan, pada pertemuan pertama peneliti menjelaskan materi pembelajaran, pertemuan kedua siswa diminta untuk melaksanakan diskusi dan presentasi dengan model pembelajaran kooperatif Think pair Share (TPS), dan pertemuan ketiga dengan melakukan evaluasi belajar siswa dari siklus II.

Observasi dan Interprestasi. Melakukan pengamatan dengan berpedoman pada lembar observasi yang telah disusun. Observasi dilakukan untuk mengetahui keaktifan siswa dalam pelaksanaan kegiatan belajar mengajar dan untuk mengetahui bagaimana pelaksanaan model pembelajaran kooperatif TPS yang diterapkan. Observasi dilakukan dengan pelaksanaan tindakan, selama observasi berlansung peneliti memantau pelaksanaan model pembelajaran kooperatif TPS serta membantu siswa yang kurang paham terhadap tugas yang mereka kerjakan dengan materi yang dibahas dan melakukan penilaian terhadap keaktifan siswa.

Hasil penerapan model pembelajaran kooperatif TPS meliputi:

(a) Visual Activities

\begin{tabular}{|c|c|c|c|}
\hline \multirow{2}{*}{ Kreteria } & \multicolumn{3}{|c|}{ Persentase (\%) } \\
\cline { 2 - 4 } & Sebelum & Siklus I & Siklus II \\
\hline BS & 0 & 0 & 5 \\
\hline B & 5 & 15 & 45 \\
\hline C & 35 & 67,50 & 50 \\
\hline K & 47,50 & 17,50 & 0 \\
\hline KS & 2,50 & 0 & 0 \\
\hline
\end{tabular}

Tabel Visual Activities Siswa Siklus II 
T. Ridanti : Meningkatkan Prrestasi Belajar ....

(b) Oral Actvities

\begin{tabular}{|c|c|c|c|}
\hline \multirow{2}{*}{ Kreteria } & \multicolumn{3}{|c|}{ Persentase (\%) } \\
\cline { 2 - 4 } & Sebelum & Siklus I & Siklus II \\
\hline BS & 0 & 0 & 22,50 \\
\hline B & 5 & 20 & 35 \\
\hline C & 22,50 & 52,50 & 42,50 \\
\hline K & 62,50 & 27,50 & 0 \\
\hline KS & 10 & 0 & 0 \\
\hline
\end{tabular}

Tabel Oral Activities Siswa Siklus II

(c) Listening Activities

\begin{tabular}{|c|c|c|c|}
\hline \multirow{2}{*}{ Kreteria } & \multicolumn{3}{|c|}{ Persentase (\%) } \\
\cline { 2 - 4 } & Sebelum & Siklus I & Siklus II \\
\hline BS & 0 & 0 & 10 \\
\hline B & 17,50 & 22,50 & 65 \\
\hline C & 45 & 62,50 & 25 \\
\hline K & 35 & 15 & 0 \\
\hline KS & 2,50 & 0 & 0 \\
\hline
\end{tabular}

Tabel Listening Activities Siswa Siklus II

(d) Writing Activities

\begin{tabular}{|c|c|c|c|}
\hline \multirow{2}{*}{ Kreteria } & \multicolumn{3}{|c|}{ Persentase (\%) } \\
\cline { 2 - 4 } & Sebelum & Siklus I & Siklus II \\
\hline BS & 0 & 0 & 7,50 \\
\hline B & 0 & 10 & 75 \\
\hline C & 65 & 67,50 & 17,50 \\
\hline K & 30 & 22,50 & 0 \\
\hline KS & 5 & 0 & 0 \\
\hline
\end{tabular}

\section{Tabel Writing Activities Siswa Siklus II}

Berdasarkan hasil observasi yang telah dilaksanakan dapat dilihat bahwa penerapan model pembelajaran kooperatif TPS dapat meningkatkan keaktifan siswa antara sebelum dan sesudah diterapkannya model pembelajaran kooperatif semua aspek, yaitu Visual Activities, Oral Avtivities, Listening Activities mencapai $100 \%$. Hal ini berarti semua aspek keaktifan siswa telah mencapai indicator ketercapaian tindakan. Jika ditinjau dari ketercapaian indicator kinerja bertujuan dari segi prestasi 34 siswa berhasil mendapatkan nilai diatas 65 , dengan kata lain $85 \%$ siswa telah mencapai indicator kinerja yang direncanakan sebesar $75 \%$. Setelah menganalisis dan mengolah data hasil observasi serta refleksi siklus II diperoleh kesimpulan bahwa kedua indicator kinerja ketercapaian tujuan penelitian, baik dilihat dari variable keaktifan maupun variable prestasi belajar siswa terpenuhi. Oleh karena itu disimpulkan bahwa tindakan kelas telah berhasil sehingga tidak perlu dilakukan tindakan perbaikan siklus berikutnya.

Hasil pelaksanaan tindakan pada siklus I dan II menunjukkan bahwa penerapan model pembelajaran kooperatif TPS (Think Paire Share) dapat meningkatkan keaktifan dan prestasi belajar siswa pada mata pelajaran IPS terpadu khsususnya Ekonomi. Peningkatan keaktifan dan prestasi belajar siswa dapat dilihat pada grafik sebagai berikut :

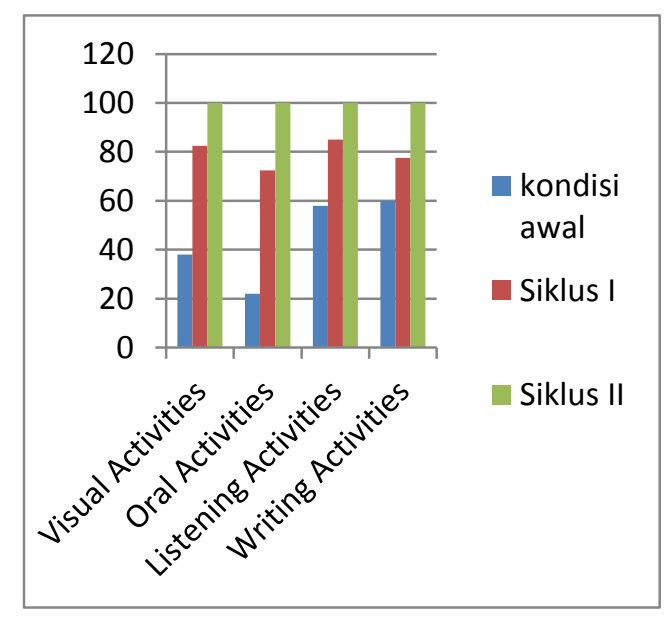

Grafik Hasil Penelitian 
Grafik tersebut memberikan informasi bahwa siklus I diperoleh hasil tingkat keaktifan pada aspek Visual Aktivies 82,50\%, Oral Activies 72,50\%, Listening Activies $85 \%$ dan Writing Activies $77,50 \%$. Hal ini berrati semua aspek keaktifan siswa telah mencapai indicator kinerja ketercapaian indicator. Dari keempat aspek keaktifan siswa terdapat tiga aspek keaktifan yang telah mencapai indicator kinerja ketercapaian tujuan tindakan, yaitu pada aspek Visual Aktivies, Listening Activies dan Writing Activies sedangkan satu aspek keaktifan yang belum mencapai indicator kinerja ketercapaian tujuan tindakan adalah pada aspek Oral Activies.

Pada siklus II diperoleh tingkat keaktifan siswa pada aspek Visual Aktivies 100\%, Oral Activies 100\%, Listening Activies $100 \%$ dan Writing Activies $100 \%$. Hal ini berarti semua aspek keaktifan siswa telah mencapai indicator kinerja ketercapaian tindakan.

\section{Pembahasan}

Nilai rata-rata kelas mengalami peningkatan, sebelum adanya penerapan model pembelajaran TPS nilai rata-rata kelas siswa adalah 66,20 tetapi setelah penerapan model pembelajaran kooperatif TPS nilai ratarata kelas siswa menjadi 69,33 pada siklus I dan 76,73 pada siklus II. Terjadi peningkatan nilai rata-rata siswa sebesar 3,13 dibandingkan sebelum diterapkannya model pembelajaran kooperatif TPS.

Berdasarkan uraian diatas dapat disimpulkan bahwa Penelitian Tindakan Kelas upaya peningkatan prestasi belajar mata pelajaran IPS Terpadu khususnya ekonomi melalui model pembelajaran Kooperatif Think Pair Share (TPS) bagi siswa kelas IX-5 SMP N 2 Babalan T.P. 2015/2016 adalah berhasil dan dapat dipertanggung jawabkan hasilnya.

\section{SIMPULAN}

Berdasarkan data berupa nilai kuis sebelum dan sesudah penelitian, dapat disimpulkan bahwa penerapan model pembelajaran kooperatif Think Pair Share (TPS) dapat meningkatkan prestasi belajar siswa. Peningkatan ini disebabkan siswa mempunyai kesempatan untuk mempelajari materi secara berulang-ulang dan kemudian memahami materi yang disampaikan oleh teman sebaya. Siswa dituntut untuk bertukar informasi atau mengajarkan pemahaman dan ingatan siswa pada materi yang dipelajari serta bertanggung jawab pada saat kuis.

\section{DAFTAR RUJUKAN}

Arikunto,S. 2010. Penelitian Tindakan untuk guru, Kepala Sekolah dan Pengawas. Yogyakarta: Aditya Media.

Aunurrahman, 2014. Belajar dan Mengajar, Bandung: Alfabeta.

Djamara, Syaiful Bahri. 2008. Psikologi Belajar Edisi 2. Jakarta: Rineka Cipta.

Hamalik, O. 2003. Metode Belajar dan Kesulitan-kesulitan Belajar. Bandung: Remaja Karya.

Sunarti. 2014. Penilaian dalam Kurikulum 2013. Yogyakarta: Andi. 
T. Ridanti : Meningkatkan Prrestasi Belajar ....

Supardan, D. 2013. Pengantar Ilmu Sosial. Jakarta: Bumi Aksara.

Susanto, A. 2015. Teori Belajar Pembelajaran di Sekolah Dasar. Jakarta: Prenadamedia Group.
Suwarsih, 2009. Penelitian Tindakan, Action Research, Teori dan Praktik. Bandung: Alfabeta.

Trianto. 2007. Model-model Pembelajaran Inovatif Berorientasi Kontruktivistik. Jakarta: Prestasi Pustaka. 